\title{
Democratic Centralism in Revolutionary China: Tensions within a People's Democratic Dictatorship
}

\author{
Douglas Howland \\ Department of History, University of Wisconsin-Milwaukee, Milwaukee, WI, USA \\ Email: dhowland@uwm.edu
}

How to cite this paper: Howland, D. (2017). Democratic Centralism in Revolutionary China: Tensions within a People's Democratic Dictatorship. Open Journal of Philosophy, 7, 448-466.

https://doi.org/10.4236/ojpp.2017.74024

Received: September 1, 2017

Accepted: October 10, 2017

Published: October 13, 2017

Copyright $\odot 2017$ by author and Scientific Research Publishing Inc. This work is licensed under the Creative Commons Attribution International License (CC BY 4.0).

http://creativecommons.org/licenses/by/4.0/

\begin{abstract}
Democratic centralism was a revolutionary strategy to reorganize society in China after 1949; it was the key governing aspect of Mao Zedong's "people's democratic dictatorship." This essay explores the tensions between democracy and centralization in the practice of democratic centralism in 1950s Shanghai. Youth and workers groups reports reveal a high degree of commitment to open debate, elections, self-organization, and new forms of leadership. Other priorities, however-a strong central state regime-would come to dominate and, after 1957, centralism and unity cancelled democracy.
\end{abstract}

\section{Keywords}

Democratic Centralism, Dictatorship of the Proletariat, Party-State, Bureaucratic Centralism, Substitutionism

\section{Introduction}

Mao Zedong and the Communist Party of China (CPC) established the People's Republic of China (PRC) in 1949 as a "people's democratic dictatorship". Mao more specifically described the PRC as an amalgam of two types of political power: The "state form" (guoti), which was a "dictatorship of the revolutionary classes of the people"; and the "government form" (zhengti), which was the system of "democratic centralism". State form represented the social class relations at the basis of the state, and government form was the state organization with which a specific social class builds its strength to defend itself against its enemies. Democratic centralism was thus the government form that the revolutionary classes would utilize in order to secure their position within a state having the form of a people's dictatorship. A synthesis of these two gives us Mao's 
shorthand description of the PRC as a "people's democratic dictatorship" (Mao, 1940: pp. 341-342; also see Knight, 1990; Steiner, 1966: 197-99; Wang, 1994: pp. 4-8, 97-100).

Mao's construction of a people's democratic dictatorship, based on his differentiation between state form and government form, was a response to the early Marxist debate over the nature of the dictatorship of the proletariat. Marx had described the dictatorship of the proletariat as the form of regime (the new hegemony of the proletariat in society) as opposed to the form of government (tasks formerly undertaken by the bourgeois state). To Marx, the dictatorship of the proletariat was but a transitional stage: it was never meant to assume a state form (Marx \& Lenin, 1988: pp. 57-59; Engels, 1891: p. 20; Lenin, 1917: p. 327; Lenin, 1918: pp. 470-471). Hence, to some Marxists, Mao's theory of the people's democratic dictatorship diverges from an appropriate understanding of Marx's theory (Balibar, 1976: pp. 46-49, 58-87, 121-123; Lin, 2006: pp. 139-140; Kraus, 1981: pp. 155-162). Mao bowdlerized Marx's argument when he identified state and government as combinatory "forms". Democratic centralism, as a governing strategy, would be useful indeed in assisting the revolutionary classes to secure their position within the new regime. But its ultimate goal ought to be the elimination of the state. As Richard Kraus has ably noted: "The irreducible point is that the state, as a device of class society, must eventually be destroyed... To Marx, all states-including the socialist state-are instruments of repression, and are only of limited duration. In such a perspective the state is by definition illegitimate." Kraus adds, regarding the CPC's administration of the state regime, "Institutionalization is essential to protecting the revolution, but it at the same time is corrupting insofar as it works against further movement" (Kraus, 1981: p. 157).

A dominant interpretation of events in 1950s China is that Chinese state management displaced Mao's revolutionary strategy of democratic centralism after 1957. The CPC confiscated state institutions and constituted itself as a state government, and this "party-state" regime asserted an authoritative position against the people and their revolutionary movement. But the party-state was not a foregone conclusion. As this essay emphasizes, youth and workers' groups in 1950s Shanghai were committed to both democratization and centralization as they participated in founding the people's dictatorship. But CPC priorities changed, as it asserted its authority in leadership.

This essay explores tensions between democratization and centralization in the practice of democratic centralism in 1950s Shanghai. What follows is based on documents found in the Shanghai Municipal Archives (Shanghai Shi Dang'an Guan), which help us to better understand the struggles between efforts to democratize and to centralize the revolutionary movement in China. To be sure, this essay is limited insofar as it is quite local and based on one set of public archives, but future research in other regional centers will complement the findings here. Part 2 below surveys official statements on democratic centralism. If these 
are rather programmatic, Part 3 examines reports made by youth and worker groups. These are remarkable for their high degree of concern for and commitment to open debate, elections, self-organization, and new forms of leadership, and they reveal that democratic centralism was indeed a revolutionary strategy for reorganizing society. Other priorities, however, would come to dominate, and Part 4 turns to the eclipse of democratic centralism in the late 1950s.

\section{Official Conceptions of Democratic Centralism in the PRC}

As the revolution moved from the countryside to the cities of China in the 1950s, two changes redefined the revolution. First, the "mass line" that had worked so successfully for the communist revolution in rural areas was recast as "democratic centralism" for urban areas. Like the mass line, democratic centralism proposed a dialectic between the masses and leadership, such that the masses would contribute problems, grievances, solutions and related ideas that CPC leadership would work into CPC policies, and the CPC would take these policies back to the masses for critique and then produce a more refined policy based on these further contributions of the masses-the dialectic would continue to develop. Democracy meant the input of everyone, and centralization meant the consolidation of policies by leadership (Mao, 1969; see also Selden, 1971: pp. 200-212, 274-276; Selden, 1995; Starr, 1979: pp. 147-151; Lin, 2006: p. 143-148; Hammond, 1978).

Second, the 1950s witnessed the extension of democratic centralism from party organization to social organization. Lenin, in 1920, had inserted the idea of democratic centralism into the USSR Party Constitution and articulated it as an operating principle for the Communist International, or Comintern. Democratic centralism thence appeared in China as a CPC rule in 1927, and two key CPC constitutions from July 1928 and June 1945 include statements on democratic centralism as a basic principle of party organization. In explaining democratic centralism, each constitution reiterates that: 1) party organizations are established through elections; 2) party organizations at all levels are required to make reports to those party members or units by whom they were elected; and 3) all lower units must accept the decisions of higher units, with a mind to enforcing decisions unconditionally. If this third point were not enough to ensure discipline and accountability, the 1945 Party constitution added the specifications that individual members must obey the party units to which they belong, that a minority must obey the majority, that lower units obey higher units, and that all must obey the Party's central committee. Discipline, obedience, and unity were constant touchstones for party organization (Constitution of the CPC, 1928; Constitution of the CPC, 1945; Liu, 2007: pp. 290-99) ${ }^{1}$.

Democratic centralism underwent considerable elaboration when Party

${ }^{1}$ Liu (2007: p. 287) notes that democratic centralism was first introduced in a June 1927 draft constitution. See also Fan Jinxue (2011: pp. 2-4, 14-18, 25-28); Lewis (1963: pp. 133-34, 196); and Wang Guixiu (1994: pp. 114-36). 
schools presented the principle in its new urban courses in the 1950s. Common to three "course topics" previewed in Shanghai municipality were the content, significance, and utility of democratic centralism ${ }^{2}$. In the first place, regarding the content and significance of democratic centralism, all three classes were to be taught that Party leaders at every level should proceed with a centralism grounded in democracy and a democracy based in centralized leadership. This applied as well to the system of assembling the broad party masses. Within the party, the conditions of democratic centralism specify that: 1) Each level of leadership and office electorally determines production. 2) Each level of leadership and office selects its own determined time to report on its work. 3) Each individual follows party organization; the minority follows the majority; the lower ranks follow the higher ranks; and local organizations follow the central organization. 4) Each person must strictly follow party organization and unconditionally uphold party decisions. Most significant is to uplift the revolutionary consciousness and activism of the broad masses of party members, and to raise their sense of responsibility to the party's work, hardening their commitment to party rules and unity, and making the work of party leadership organs more harmonious and correct.

In the second place, regarding the utility of democratic centralism, all three course topics emphasize that first, democratic centralism is based in democracy and democracy follows central leadership. As a result, the entire party practices united party regulations and rules and follows unanimously a democratically elected party leadership. Yet the party's iron rules must not restrict a party member's creative spirit and democratic rights, for all party members have equal duties and rights to oppose individual despotism within the party, and to engage in criticism and self-criticism-especially criticism of those above and below. In order to practice a high degree of democracy, one must practice a high degree of centralism. Second is the matter of party members' conception of organization and the life of the organization. To completely fulfill one's duties and to utilize a party member's rights is to express an unlimited sincerity to the party. Democratic centralism within the party must accordingly encourage each member to develop an attitude toward party organization of "say all that you know and say it without reserve" (zhiwubuyan, yanwubujin). Each member must personally and unconditionally follow organizational control, for the organizational life of the party member is to safeguard and to advance the collective work (see SSDG: A76-2-212-16).

As I have noted, the precepts of this Party doctrine echo organizational statements from earlier decades. New in the 1950s is the democratic appeal to workers. The second and third course topics specifically address new party members

${ }^{2}$ This discussion is based upon records of 3 party school course discussions available in the Shanghai Municipal Archives (Shanghai Shi Dang'an guan; hereafter abbreviated SSDG): The first document was prepared for a 1953 course [A76-2-212-16]. The second document was written in 12/1952 for a 1953 course [A76-2-212-17]. The third document makes a reference to the "tumultuous movement of 1958"; hence it must date from 1959 or 1960 [A76-2-276-19]. 
from the urban working class. They emphasize that the CPC is a proletariat party and not just a party for the party's sake, that democratic centralism has to do with the relation between leaders and those who are led, and that democracy and centralism are not an opposition but a unity. Democracy raises party activism and initiative; centralism safeguards party unity. As a worker's party, the CPC is not an authoritarian or tyrannical organization. As a worker's party, unity gives the group strength-particularly to carry out the movements encouraged by the party center, such as the "three-anti", "five-anti", and the democratic revolution. (See below.) When the entire party is of one mind, it succeeds; without unity, the party's work will suffer. Thus the party must unite under leadership; this is centralism (SSDG: A76-2-212-17).

More specifically, democracy for a workers' party means that elections take place at every level for leaders and representatives. Each level makes a report on its work to present at conference. Each individual follows party organization; the minority follows the majority; lower ranks follow the higher ranks; and localities follow the center. Unity is the result. Thus all strictly maintain party regulations and unconditionally carry out party resolutions. Democracy is thus built on centralism and centralism is directed downward to democracy; the upper ranks of leaders reach to the broader ranks of members below (SSDG: A76-2-212-17).

In addition to elections, the party and the people are integrated through the mass line. The second and third course topics note that the party's democratic centralism is based on broad party membership and system of organization, whose working method is the mass line. When the party undertakes anything, it's not enough to rely on a minority of people, but it must rely on the people's needs and the ideas of the great majority (SSDG: A76-2-212-17). Leadership must follow the principle "from the masses to the center, from the center to the masses" (SSDG: A76-2-276-19).What the party puts into practice produces ideas that can then reflect back to the higher ranks, so that the party links higher and lower. This is how the masses and leadership are related. The working class's strength is in this organization, and unity is the goal of democratic centralism.

These documents are quite candid in noting problems with democratic centralism and party leadership. The second course topic admits that some party members don't see party organization as it is constructed and act arbitrarily or authoritatively, without consulting the larger group. The individual is supposed to represent party organization, not pose a danger to democracy. The third course topic suggests ways to strengthen democratic centralism: to fulfill responsibilities; to expand education; to exercise collective leadership and divided responsibilities; and to use communist thought to combat bourgeois individualism. Are these mere platitudes or topics for further discussion? We don't know because nothing more is offered to illustrate these important suggestions.

\section{Democratization and Centralization in 1950s Shanghai}

In his speech of April 1945, "On Coalition Government", Mao had announced 
his intention to extend democratic centralism from party organization to the government of the entire country (Mao, 1945) ${ }^{3}$. As a central element of the stage of "New Democracy" announced in 1949, democratic centralism became a technique of national governance for the urban phase of revolution that would lead the revolution to socialism (see Barnett, 1964: pp. 15-17). "New Democracy" had been proclaimed as "the political foundation for the national construction of the PRC" in the "Common Program of the Chinese People's Political Consultative Conference" in September 1949 (The Common Program of the Chinese People's Political Consultative Conference, 1949: p. 35). To that end, the CPC established and expanded new mass organizations such as cadre schools and youth organizations, sponsored mass movements such as the "three-anti" and five-anti" campaigns, and began to socialize industrial production and labor unions ${ }^{4}$. As the largest urban center in China, Shanghai in the 1950s was a fertile ground for the experimental development of a socialized economy and democratized society ${ }^{5}$.

The CPC officially encouraged democratization with the enactment of the 1953 Electoral Law, which mandated the creation of not only the All-China (or National) People's Congress, but also local people's congresses at the county, municipality, and provincial levels, which were to replace existing local governments (Electoral Law of the PRC, 1953) ${ }^{6}$. In multiple ways, democracy took hold in major cities distant from Beijing, including Shanghai, Wuhan, and Canton (Guangzhou). When the land reform movement arrived in the south after 1949, the CPC popularized "planning consciousness" in order to mobilize the people in preparation for the first five-year plan of 1953. The democratization of Canton was further encouraged by a bureaucratic reorganization, such that Canton no longer reported to Beijing, but to a staff office at the provincial level (Vogel, 1969: p. 127). In keeping with the new democracy, the CPC and the five-anti campaign in Shanghai enlisted the bourgeoisie in the struggle for socialism. Those who were "punished" were rather leniently reformed because the Party wanted the bourgeoisie to continue to direct production during the transition. At the same time, the CPC insisted on joint participation in the movement; workers were criticized for "excessive democracy" when they made their own unsupervised inspections and arrests (Barnett, 1964: pp. 144-152; Gardner,

${ }^{3}$ On democratic centralism as a structure for government organization, see Barnett (1964: pp. 15-17). Barnett asserts that "democracy" means "equalitarianism" to members of the CPC-the abolition of privilege so that all were treated according to their equal rights.

${ }^{4}$ On the expansion of cadres after 1949, see Vogel (1969: pp. 51-60) and Jiang and Shao (2001: pp. $325-333,336,338,345)$. On mass organizations, see Barnett, (1964: pp. 29-44) and Walker (1955: pp. 36-42).

${ }^{5}$ Shanghai's socialist economic development is celebrated in Zhonggong Shanghai shiweidangyanjiushi, ed. (2011, vol. 1: pp. 9-34). The set of oral histories therein includes a reminiscence of workers Shen Liming, Yang Shangiu, and QianChengzhi, on 1950s industry and the five-anti campaign: “1952 nian Shanghai zhiyuan Dandongriyonghuaxuegongyeqingkuang” (vol. 1: pp. 205-208).

${ }^{6}$ These elected congresses were subsequently written into the first Constitution of the People's Republic of China (20 September 1954); see Chapter II, Section I for the National People's Congress (pp. 11-16) and Chapter II, Section IV for the Local People's Congresses and Local People's Councils (pp. 20-24). 
$1969)^{7}$. And in the course of the three-anti campaign, the CPC began to encourage "people's letters" (renminlaixin) as a new form of popular feedback; in conjunction with the new local people's congresses and the supervisory network of informants who investigated cadres and their work, the masses were encouraged to write comments and complaints to provincial and central government offices, as a form of both "popular supervision" and "popular opinion" (Barnett, 1967: pp. 77-78, 139; Harding, 1981: pp. 61, 83-84).

A report issued by the Shanghai branch of the China Youth Organization in June 1956, on the eve of an election of delegates to the Third Plenary Meeting of the Shanghai Youth Organization, highlights a key aspect of democratic centralism as its practice evolved in the 1950s. The report admitted that although democracy and centralism cannot be separated, one can sometimes be emphasized over the other. At that moment, it was appropriate to emphasize democracy, particularly as the business at hand was for the nearly 1000 members of the organization to elect 100 delegates to attend the meeting. Hence the Youth Organization's discussion of democratic centralism paid more attention to democracy. According to their report, the essence of democracy is to develop the initiative and enthusiasm of the entire body of members and to raise their feeling of responsibility toward the organization; to firmly establish a "master's" way of thinking regarding the organization (rather than think of oneself as a mere "follower"); and to develop the organization's collective consciousness in order to discuss and study the work of the organization. Although some comrades think that developing democracy is more or less to bring ideas to the leaders, that idea does not sufficiently cover the matter (SSDG: A71-2-532-12).

The report went on to outline the qualities of democracy: First, leaders must publicize the work of the organization's meetings, the meetings of representatives, and each person's own work. Both members and representatives should have the attitude of a master, because they are all collectively the head of the organization. It is wrong to think that the organization's work is only for the cadres or cadre leaders; it is each one's own work to study and discuss and the group should rely on themselves collectively. Second, all leadership positions within the organization are democratically elected, from cadres to central authority. There is no leadership class. To think so is a misunderstanding due to the new establishment of the organization. Third, all bodies within the organization should practice collective leadership. Democratic discussions should be decided by the opinions of the majority and then put into practice. No one should tyrannize against the majority, because democratic discussion alone will ensure that the work is more correct and will help everyone to combat subjectivity, to avoid errors, and to improve the work. And fourth, during discussions at member meetings, each person is free to express his/her own ideas, including questions and criticisms, even of leaders. Leaders who suppress democracy should be reported to the organization central committee. Moreover, the authors of the

${ }^{7}$ Liu Shaoqi would later (during the Cultural Revolution) be castigated for sponsoring this policy; see Brugger (1976: pp. 6, 67-68) and Teiwes (1990: pp. 41-42, 71-76, 150). 
report recognize that outsiders to the Youth Organization may criticize or comment on the work, both to more broadly absorb the ideas of the masses and to improve the work.

The qualities of centralism, by comparison, were treated quite briefly and echo a refrain we have seen in the party documents above. Organization members must strictly maintain organizational order: the minority follows the majority; the lower ranks follow the higher ranks; the individual follows the group. Nonetheless, the document does address minority points of view. If it appears that the majority is making all decisions, and if there are different opinions, then the discussion may open a debate in which each person offers his/her own ideas. But when a majority opinion is reached, there must be unconditional agreement, for this is the rule of organization. If other ideas persist, keep them, but the organization cannot support individual ideas, in order to maintain organization, unified action, and proceed with one mind, lest the group lose its strength.

Lest we treat this discussion of democratic centralism as purely or merely ideological, consider a pair of documents from Shanghai that suggest a sincere effort both to democratize in the workplace and to socialize what had been a capitalist enterprise. Both of these date from a pivotal moment in Chinese industrial development-1957-when democratization in the workplace confronted two rival forces, both "enterprisation", the effort to redefine factories and companies according to the evolving network of economic administration, and centralization as the set of efforts to create economic administration in both economic planning departments and all-China union organizations. Both enterprisation and centralization reflect the growth of bureaucracy in the 1950s, as the party and state attempted to unify its rule through the development of centralized policy, while democratization worked against the development of vertical hierarchies of rule in favor of local control (Brugger, 1976: pp. 7, 15-16, 67, 83).

In the first document, a Shanghai branch of the Sanyang (San'yō) Corporation reported in 1957 on the challenges of reconstructing the company in the past year (SSDG: B123-3-1002-20). It raised several interesting questions: How are they to improve their products, their production, advertising and sales, and do so both collectively and democratically? It is an enterprise of 55 employees, nine in management, with two CPC cadres in the group. The cadres want to engage combatively among the employees-with accusations and denunciations-but the writers of the report fear that this way of thinking fails to understand the nature of the company. Instead, they've broken everyone up into 18 small groups for study and discussion, with a goal to understanding that this must become a socialist company-that is, there must be group effort and group management. They want to raise the level of thinking and advance the collective work of the company. What is the right attitude to take toward management, as they transform a capitalist company into a socialist one? One important task was to formulate rules for the workplace, as though each person were a "master" in charge of the company. Hence the groups collectively decided that there should be no casual eating on the job and that smoking breaks should be managed ac- 
cording to rules. Procedures of criticism and self-criticism were engaged, and employees' experiences in the company provided examples for discussion-cutting corners in production, delays in deliveries, and so on, as well as personal failures in fulfilling assignments.

The groups opted to strengthen political thinking by promoting the habit of "thinking like a master" and actively promoting democracy and collective action through elections. First they elected a committee of nine representatives to constitute a company management committee. What, if any, conditions should there be for election to the committee? Should elections be made by private vote or public affirmation? How do they make representatives reflect the ideas of the group? (This reflects the perennial issue of negotiating the public and private aspects of an individual as a representative.) Behavior is directed toward improving the work of the company: such a principle unites the representative's ideas with those of the masses. The two party cadres were publicly elected to the management committee; we don't know if there was pressure to elect them or if they were rewarded for their good work. But the writers of the report noted that democratic elections have a salutary effect in that they serve as exercises in thought education, and that the small groups were the right place to introduce the cadres as potential leaders.

After the elections (conducted in the small groups), the company resumed meeting as a whole group, for democracy must return to the working group and the management of the company. This is the start of socialism and the confronting of contradictions-i.e., the former class differences and the fact that those who do the work should participate in management. The education of political thought must be a priority, by analyzing the company and the work structure. Each should ponder his/her relation to the company, and ask how bureaucratism affects the work of the company ${ }^{8}$.

A second document, a 1957 report on activities undertaken by a construction labor union during 1956, similarly recounts attempts to improve the democratic life of the union and problems that arose (SSDG: C12-2-96-149). Their work suffered in two ways. First, their union members are typically split between two locations of operations, so it is hard to call everyone together and to communicate with everyone and to get everyone to express their opinions. The writers admit that the results of labor union meetings are bad and need serious improvement. Second, there are serious disagreements and problems between the party cadres at the two locations. The masses are different at the two locations and, at one, the level of education among the activists is low, the work is quite busy, and so the movements that the cadres attempt go badly. This produces unwholesome problems in the masses' thinking. As a result, meetings fail to take place, so that people don't know what to do. There are no small group meetings regarding workers' quality of life. The activist meetings for movements are ${ }^{8}$ This report confirms Brugger's finding (1976: pp. 103-105, 131-32) that democratization was a key means by which workers were inserted into management in the early 1950s. On the use of "small groups" for social transformation, see Whyte (1974), Chapter 8 for workers. 
scheduled for every Thursday but the labor union hasn't adequately planned for these, so that for three or four months there were no livelihood meetings. There is rarely thought education for the union members, and the union members raise the question of the insufficiency of education among their ranks, so-on the judgment of the report-their behavior in this respect is completely correct. Hence, the writers of the report conclude that the problem lies with the cadres, whose administration is too lax, whose management of the work does not follow the lead of the masses, and whose leadership goes contrary to the sensibility of the masses, so that the activists in the group are undercut. In short, the cadres mislead the activists and take no account of the issues that the latter raise. The work of the activists does not accord with the ideas of the cadres; the cadres don't engage the activists, and the result is that the relations between the labor union and the masses are not close.

The writers recommend that they must, first, centralize the question of the labor union's democratic life. They must expand thought education for both the cadres and the activists and democratic education for both the labor union and the masses. Second, the union's activities need to be adjusted. The 300 to 400 members must review the work of the cadres and replace them if necessary, and thus bring forth names from the masses so that the workplace and the companies have better cadres and so that production improves. Third, the democratic system must be connected to the workers. The union meeting must be joined with the masses to ensure that there is time to link up with movements and so that the union can link up with the work of the activists. Union meetings of all members should proceed once or twice a month for the time being, to reinforce the fact that the union is within the masses. And fourth, the cadres should be assisted in taking the view of the masses. The union must work with them to better organize union meetings and to improve the organization of the activists; this will improve the union's management of the activists.

The seriousness with which democratic reform was undertaken and democratization was emphasized in the 1950s is underscored by a fascinating record of a discussion within the Industrial Production Committee of the Shanghai branch of the CPC regarding the differences between the Soviet Union's style of "one-man rule" (yizhangzhi) and China's democratic centralism (SSDG: A38-2-445-78) $)^{9}$. Those who defended one-man rule argued that production was served best by one-man rule because it created a rigorous unity: leaders were appointed rather than elected and all decisions were made by an individual rather than by conference. If there were no agreement among all parties, one could refer the question to higher ranks but, the Committee admitted, in the absence of a policy, one risked creating confusion. Defenders of democratic centralism challenged their opponents on the basis of unity: although one-man rule need not consult the masses, the joint input of both leaders and masses created a bet-

${ }^{9}$ This report has a title: Zhonggong Shanghai shiweigongyeshengchanweiyuanhui, "Yizhangzhiyuminzhujizhongzhi you he qubie de dafu"-baogao. 
ter basis for unity. Given the critical context of industrial production-national independence and sovereignty-democratic centralism was a more reasonable basis for advancing production and economic development. As Brugger's research has indicated, the tension between one-man leadership and a more democratic organization would persist in Chinese industry through the 1950s. In the absence of sufficient numbers of knowledgeable workers who might serve as managers, one-man rule was the easier and more efficient route, but once greater expertise was generalized, forces for a more democratic management grew (Brugger, 1976: pp. 10-11, 188-189, 250-255). As the management committee of a soap factory in Shanghai put the issue in 1955, democratic centralism was neither an individual dictatorship nor extreme democratization; the question was how to maintain a "spirit of democracy" within the spirit of democratic centralism (SSDG: A48-1-351-7).

\section{Democratic Centralism Suspended after 1957}

In spite of these multiple efforts to encourage the people to see themselves as masters in a revolutionary China, democratic centralism failed to produce the system for which it was intended. The socialist transformation that was undertaken in the 1950s-particularly in urban China-created a party-state regime that controlled all aspects of society and economic life ${ }^{10}$. Although democratic centralism and its predecessor, the mass line, were intended to provide linkages between the party and the people, authority in 1950s China increasingly extended downward, from party central to localities. Democratic centralism in the 1950s was deformed by what Hong Yung Lee has identified as "the unintended consequence of blending policy debates with the struggle for power" (Lee, 1991: p. 397). The CPC's efforts to remove the Nationalist Party from government offices and their capitalist supporters from industry informed simultaneous efforts to organize workers, youth, and women for the revolutionary transformation to socialism. Lee argues that "For the sake of making a socialist revolution, the party... completely penetrated not only all the auxiliary mass organizations but also the state apparatus, imposing 'monistic' leadership and thereby losing the flexibility that the layered organizations had previously offered" (Lee, 1991: p. 69).

One key aspect of this failure is that, as the "liberation" of the 1940s turned to the task of integrating the urban centers of China into a larger "socialist revolution", the mass line was replaced with mass mobilization. Where the mass line sought the political penetration of society and the integration of people and party, and addressed the interests and needs of persons and groups in rural China, mass mobilization in the cities of the 1950s increasingly pursued class warfare and implemented policies directed by top leadership.

${ }^{10}$ The demise of democratic centralism followed the end of New Democracy. Because of the success of the social movements of 1951-1952 and the recovery of China's industry, Mao proposed to suspend the stage of New Democracy and encouraged the shift to socialism in 1953. Teiwes (1990: pp. 54-59) points to Mao's speech of 15 June 1953 at the Financial and Economic Conference as the point at which Mao encouraged this redefinition of the PRC's general line. 
The party initiated a series of social movements that eventually eliminated any social force that could have made demands or worked to check the ever expanding party-state (Lee, 1991: pp. 71, 199). The first of these movements were deliberately committed to inclusion and democratization-their purpose was, after all, to mobilize the people and to involve them in social, political, and economic reconstruction. The "three-anti" and "five-anti" campaigns of 1951-1953 successfully granted the party and its cadres access to industry and began to socialize capitalist factory production; in cities such as Canton and Shanghai, as noted above, these movements and transitions proceeded with an emphasis on democratic participation. Democratic centralism meant that in addition to criticizing government and industrial leaders and administration, the party too was scrutinized and criticized for its work. Mass participation in political campaigns was linked with the new election law for local people's congresses-their common denominator was the nexus of cadres engaged with the people (Barnett, 1964: pp. 135-171; Ching: 1957; Harding, 1981: pp. 51-62 $)^{11}$.

The "anti-rightist" campaign in 1957, however, redirected Mao's and the CPC's social revolution and began to solidify a party-state. The 1950s tensions between enterprisation and democratization in industry, and centralization and decentralization in CPC and state government policy were resolved in favor of a vigorous centralization. The anti-rightist campaign attacked overstaffed bureaucracy, nonparty cadres, and intellectuals, with two important results: First, no one dared to challenge the party after 1957; citizens had been warned against criticizing party and state. Second, party cadres came to dominate the party-state, insofar as nearly all county-level and district-level administrations were in the hands of party cadres (Lee, 1991: pp. 57-65). As we saw in the Youth Organization statement above, the unity of democratization and centralization meant that one can sometimes be emphasized over the other, but after 1957, centralization was the dominant strategy.

At the same time, Mao began to conceptualize a "Chinese road to socialism", a process both different from the Soviet model and one destined to undergo perpetual struggles because of dialectical contradictions among the people. To Mao, the party rightly dominated this process-the CPC could see the entire situation and enlist the support of the masses in the immediate struggle. Although Mao insisted that consultation should still play a part in policy formation, he noted that the earlier period of the revolution had been dominated by "excessive decentralization." In his pivotal speech of 1957, "On the Correct Handling of Contradictions among the People", Mao was quite confident that the People's Government "genuinely represents the people's interests... [and] serves the people" (Mao, 1957: p. 434). Ultimately, the strong central state mattered most, and in the practice of democratic centralism after 1957, centralism and unity became more important than democracy. With the onset of collectivization in agricul-

\footnotetext{
${ }^{11}$ A hostile assessment is Walker (1955: pp. 77-100). See also Wu Zhongyan's (1985-1986) testimony of his work as a cadre in 1950s Wuhan and the cases reported in Whyte (1974, Chapter 5).
} 
ture, unity began to imply a monolithic pattern for the sake of national integration and forsook local conditions (Knight, 2007: pp. 221-227, 249-255; Lin, 2006: pp. 79-81; Schram, 1989: pp. 102-118) ${ }^{12}$. Likewise, the conditions of state censorship encouraged the people to engage in self-scrutiny and to produce a uniformity in public expression that misrepresented a unity of interests (see Davies, 2011).

Mao argued in 1957 that, because the people's democratic dictatorship was a superstructural element in the service of the economic base, it was mutable:

Those who demand freedom and democracy in the abstract regard democracy as an end and not a means... Both democracy and freedom are relative, not absolute, and they come into being and develop in specific historical conditions. Within the ranks of the people, democracy is correlative with centralism and freedom with discipline... we cannot do without freedom, nor can we do without discipline; we cannot do without democracy, nor can we do without centralism. This unity of democracy and centralism, of freedom and discipline, constitutes our democratic centralism (Mao, 1957: p. 438).

Mao subsequently added that democratic centralism represents the work of resolving contradictions among the people in order to produce the consolidation of viewpoints under the unity of Party leadership ${ }^{13}$. This version of democratic centralism drew especial criticism that Mao had simplified his analysis of social and class relations in China and substituted the supraclass categories of "the people", who support the CPC, and their "enemies", leaving the Party as an absolute and exclusive power (Mao, 1962; see also Lew, 1975: p. 146; Meisner, 2007: pp. 111-112; Starr, 1979: pp. 109-115, 205, 215-216). In the final analysis, new democracy and its state form of democratic centralism was a transitional structure, facilitating policy shifts in the direction of socialism. To many Marxists, this capacity of superstructural elements to influence or determine the economic base remains a highly controversial aspect of Mao's theories of new democracy and Chinese socialism, and his form of Marxism generally. The relationship between society and state in Mao's theory makes it clear that such mutual interaction between the economic base and superstructural elements was always a primarily formal aspect of Mao's interpretation of socialist revolution (see Cohen, 1964: pp. 115-122; Dirlik, 1997: pp. 65-77; Healy, 1997: pp. 141-145).

The centralization that Mao wanted in order to pursue programmatic economic development made a necessity of bureaucracy. Centralized planning required a hierarchy of party-state officials from the center to the provinces, cities, and counties, and this centralization was valued for the sake of the uniformity that it imposed-but uniformity was a poor substitution for unity and meant the ${ }^{12}$ The importance of centralism under party leadership persists today; see Liu (2007: pp. 93-119). Another writer, Fan Jinliang, stresses the leadership of party and nation (Fan, 2001: pp. 53-63). ${ }^{13}$ Stuart Schram favorably compares Mao's "people's democratic dictatorship" - with its goal of unity-to Rousseau's notion of “general will”. See Schram (1969: p. 96) and Schram (1989: pp. 88-90) on unity and integration (yiyuanhua). 
loss of contact between the CPC, its cadres, and the masses. Bureaucratization was part of the solution for systematic development, and it came at the cost of creating a party-state regime (Kraus, 1981: pp. 4-8, 73-79) ${ }^{14}$.

Bureaucracy continued to grow both in spite of and according to Maoist criteria. In the 1940s, cadres had been the backbone of the revolution as it expanded in rural China, and they were then defined by their superior political consciousness, which qualified them to assume responsibility for political tasks in leading the revolution. After 1949, with the huge expansion of their numbers to foster the urban revolution, cadres came to be identified as anyone who was paid by the state budget and not engaged in productive manual labor. In the 1930s and 40 s, cadres were evaluated on the basis of their "virtue" or political loyalty and reliability, their ability to mobilize people, and their seniority (as to when they joined the party). Yet in the course of the 1950s, virtue-narrowly defined as "class background" as a mark of loyalty to the party-came to dominate evaluations of cadres and encouraged what many have described as a pernicious commitment to their superiors within the party state; at the same time, the "life tenure system" of a cadre in a unit invited leaders to "privatize" their formal authority. These developments not only encouraged the creation of cliques within the bureaucratic party-state but also facilitated the growing denigration of competence or specialized knowledge-the paradigm of "red over expert" (Lee, 1991: pp. 4, 8, 65-66, 69; Barnett, 1967: pp. 39-47; Brugger, 1976: pp. 154-155, 242-243, 263; Vogel, 1967; Friedman, Pickowicz, \& Selden, 1991: pp. 104-110).

In spite of Mao's several attempts to undermine and reduce the bureaucracy, two figures are telling: first, that the number of cadres in China increased eight-fold from 1949 to 1958; and that the cadre-to-citizen ratio grew from one cadre per eighty citizens in 1956 to one cadre per fifty citizens in 1982 (Kraus, 1981: p. 73; Lee, 1991: p. 207). Even in the wake of the "reforms" of the 1980s, "the party ordinarily maintains tight control over administrative as well as other functional bureaucracies, rendering meaningless organizational distinctions among the party, the state, enterprise units, and business units. The party not only has its own bureaucratic hierarchy paralleling the state structure, but it also penetrates every formal organization and institution...” (Lee, 1991: p. 203)

The Chinese bureaucracy continues to monopolize political authority without being accountable to anyone but top political leaders, whose authority is derived from their offices within the party-state bureaucracy. After 1957, the boundary became blurred between the party, on the one hand, and state organs and organizations on the other. The party-state came to control most aspects of economic activity-planning, financing, the circulation of products and the allocation of labor. The elimination of a labor market and the introduction of the state allocation system gave the party-state control over social mobility, and individuals lost control over crucial decisions such as savings, consumption, occupational choice, and physical movement across administrative boundaries (Walder,

${ }^{14}$ Teiwes (1990: pp. 17-18) notes that unity in the 1950s was assisted by Mao's unquestioned leadership. 
1986: pp. 28-84; Lee, 1991: pp. 71, 393). At the same time, the official ideology continued to emphasize class and to claim that the party-state represented the proletariat. Lee observes that the class basis (and bias) of the party and its cadres after 1957 foreclosed any balance between social revolution and economic construction. Yet the regime did not particularly further working class interests. Leaders predetermined the interests of workers and ignored input from the masses, even if cadres were supposed to both investigate local conditions and mobilize those masses on behalf of party-state policies. The party-state's accountability to society declined (Lee, 1991: pp. 66, 393-96). Mao would fight repeatedly against this development in order to recover some integration between the cadres and masses; first in the rather lackluster socialist education movement of 1962, and then with frightening success in the Cultural Revolution of 1966-68, at which point he recoiled against the anarchic forces that he himself had set free to make revolution (Harding, 1981: pp. 201-208, 246-263; Kraus, 1981: pp. 11-18, 81-88).

In abandoning the all-important work of consultation and integration, mass mobilization undercut the democratic centralism epitomized by the mass line. As a result, the majority of people, the peasants, found their interests undermined by policies created far away in Beijing. Where radical participation in the revolution had flourished when party cadres and local activists focused on their material conditions of life, these revolutionary developments were displaced in the 1950s by central government directives that were increasingly irrelevant to the peasant majority and, worse, arguably damaged their material conditions. Mass mobilization diverted the revolution toward the creation of a party-state, marked by party domination, the expansion of bureaucracy, and the development of patron-client relations (Blecher, 1991; Lin, 2006: pp. 136, 148-149, 156-160; Friedman, Pickowicz, \& Selden, 1991: pp. 132-245; McCormick, 1990: pp. 6, 20-23, 60-93; Thornton, 2011; Tsou, 1986: pp. 269-273, 276-279; Weatherley, 2006: pp. 34-35; Wong, 2005: pp. 36, 47-57).

\section{Conclusion}

This creation of a party-state is precisely what Leon Trotsky had denounced in the Soviet Union as "substitutionism": the party had come to act as a proxy for the proletariat when it assumed that it could speak on behalf of workers (and eventually peasants). In Trotsky's analysis, the democratic revolution of workers' soviets in Russia had been supplanted on two accounts: initially by the bourgeois revolt represented in the Duma, and then by the Bolshevik Party, as it transformed a proletarian democracy into a proletarian dictatorship under the leadership of the Party. As would happen in the PRC, the rights of workers to express demands and to criticize those in power were curtailed in the interests of discipline and a centralism focused on economic development. The Party felt justified to ignore workers' wishes and desires. Under the leadership of the Soviet Party's Central Committee, party centralism had evolved into a bureaucratic 
centralism. Trotsky argued that only a measure of proletarian democracy for workers and peasants would curb the expansion of bureaucracy and the privileges that it induced, and then reassert a true democratic dictatorship of the proletariat (Deutscher, 1954: pp. 90-92, 318-319; Deutscher, 1959: pp. 12-16, 463-465; Deutscher, 1963: pp. 33-36; Knei-Paz, 1972: pp. 192-98; Cliff, 1960: pp. 14-17, 22-26; Trotsky, 2010: pp. 83-85, 253-259).

In China, by comparison, the CPC has continued to express its commitment to democratic centralism in party and state documents. Significantly, the electoral reforms of the 1980s and the success of village elections were justified with reference to democratic centralism (Howland, 2012). As Marx and Lenin had theorized, the dictatorship of the proletariat can transform society as a radically democratizing regime, without assuming the trappings of bourgeois state government. That said, the dictatorship of the proletariat remains a generally practical problem within Marxism, for many a regime did not figure out how to eliminate the bourgeois state form that it had conquered. In its Maoist guise as the people's democratic dictatorship in China, it continues to uphold a state regime committed to centralization and the appearance of unity.

\section{References}

Balibar, E. (1976). On the Dictatorship of the Proletariat, trans. Grahame Lock. London: NLB.

Barnett, A. D. (1964). Communist China: The Early Years 1949-55. N.Y.: Praeger.

Barnett, A. D. (1967). Cadres, Bureaucracy, and Political Power in Communist China. N.Y.: Columbia University Press.

Blecher, M. (1991). The Contradictions of Grass-Roots Participation and Undemocratic Statism in Maoist China and their Fate. In B. Womack (Ed.), Contemporary Chinese Politics in Historical Perspective (pp. 130-40). Cambridge: Cambridge University Press. https://doi.org/10.1017/CBO9780511664250.006

Brugger, W. (1976). Democracy and Organisation in the Chinese Industrial Enterprise (1948-1953). Cambridge: Cambridge University Press.

Ching, C.-H. (1957). San Fan-Wu Fan-The Big Cleanup. In China in Transition: Selected Articles 1952-1956, ed. China Reconstructs (pp. 144-149). Peking: China Reconstructs.

Cliff, T. (1960). Trotsky on Substitutionism. International Socialism, Ser. I, No. 2, 14-17, $22-26$.

Cohen, A. A. (1964). The Communism of Mao Tse-tung. Chicago: University of Chicago Press.

Common Program of the Chinese People's Political Consultative Conference (1949). In A. P. Blaustein (Ed.), Fundamental Legal Documents of Communist China (pp. 34-53). South Hackensack, NJ: Fred B. Rothman \& Co., 1962.

Constitution of the Communist Party of China (1928). In T. Saich (Ed.), The Rise to Power of the Chinese Communist Party: Documents and Analyses (pp. 376-86). Armonk, NY: M.E. Sharp, 1996.

Constitution of the Communist Party of China (1945). In T. Saich (Ed.), The Rise to Power of the Chinese Communist Party: Documents and Analyses (pp. 1254-1267). Armonk, NY: M.E. Sharp, 1996. 
Constitution of the People's Republic of China (1954). In A. P. Blaustein (Ed.), Fundamental Legal Documents of Communist China (pp. 1-32). South Hackensack, NJ: Fred B. Rothman \& Co., 1962.

Davies, G. (2011). Homo Dissensum Significans, or the Perils of Taking a Stand in China (pp. 29-56). Social Text No. 109. https://doi.org/10.1215/01642472-1416082

Deutscher, I. (1954). The Prophet Armed: Trotsky, 1879-1921. Oxford: Oxford University Press.

Deutscher, I. (1959). The Prophet Unarmed: Trotsky, 1921-1929. Oxford: Oxford University Press.

Deutscher, I. (1963). The Prophet Outcast: Trotsky, 1929-1940. Oxford: Oxford University Press.

Dirlik, A. (1997). Modernism and Antimodernism in Mao Zedong's Marxism. In A. Dirlik, P. Healy, \& N. Knight (Eds.), Critical Perspectives on Mao Zedong's Thought (pp. 59-83). Atlantic Highlands: Humanities Press.

Electoral Law of the People's Republic of China (1953). In A. P. Blaustein (Ed.), Fundamental Legal Documents of Communist China (pp. 193-214). South Hackensack, NJ: Fred B. Rothman \& Co., 1962.

Engels, F. (1891). Introduction. In K. Marx, \& V. I. Lenin (Eds.), The Civil War in France: The Paris Commune (2nd ed.). New York, NY: International, 1988.

Fan, J. (2001). Minzhujizhongzhi zhuantiyanjiu [Studies on the Topic of Democratic Centralism]. Ha'erbin: Heilongjiang Renminchubanshe.

Fan, J. et al. (2011). Minzhujizhongzhi xianfa: yuanze yanjiu [Democratic Centralist Constitutions: A Study of Principles]. Shanghai: Dongfangchuban zhongxin.

Friedman, E., Pickowicz, P., \& Selden, M. (1991). Chinese Village, Socialist State. New Haven, CT: Yale University Press.

Gardner, J. (1969). The Wu-Fan Campaign in Shanghai: A Study in the Consolidation of Urban Control. In A. D. Barnett (Ed.), Chinese Communist Politics in Action (pp. 477-539). Seattle, WA: University of Washington Press.

Hammond, E. (1978). Marxism and the Mass Line. Modern China, 4, 3-27. https://doi.org/10.1177/009770047800400101

Harding, H. (1981). Organizing China: The Problem of Bureaucracy 1949-1976. Stanford, CA: Stanford University Press.

Healy, P. (1997). A Paragon of Social Change: Mao Zedong on the Social Formation and Social Change. In A. Dirlik, P. Healy, \& N. Knight (Eds.), Critical Perspectives on Mao Zedong's Thought (pp. 117-153). Atlantic Highlands, NJ: Humanities Press.

Howland, D. (2012). Popular Sovereignty and Democratic Centralism in the People's Republic of China (pp. 1-25). Social Text, No. 110.

https://doi.org/10.1215/01642472-1468299

Jiang, J., \& Shao, Y. (2001). Zhonggong Shanghai dangzhi [The Shanghai Branch of the Chinese Communist Party]. Shanghai: Shanghai shehui kexueyuanchubanshe.

Knei-Paz, B. (1972). The Social and Political Thought of Leon Trotsky. Oxford: Oxford University Press.

Knight, N. (1990). On Contradiction and on New Democracy: Contrasting Perspectives on Causation and Change in the Thought of Mao Zedong. Bulletin of Concerned Asian Scholars, 22, 18-34.

Knight, N. (2007). Rethinking Mao: Explorations in Mao Zedong's Thought. Lanham: Lexington Books. 
Kraus, R. C. (1981). Class Conflict in Chinese Socialism. New York, NY: Columbia University Press.

Lee, H. Y. (1991). From Revolutionary Cadres to Party Technocrats in Socialist China. Berkeley, CA: University of California Press.

Lenin, V. I. (1917). The State and Revolution. In Selected Works (pp. 264-351). New York, NY: International, 1971.

Lenin, V. I. (1918). The Proletarian Revolution and Renegade Kautsky. In Selected Works (pp. 468-75). New York, NY: International, 1971.

Lew, R. (1975). Maoism and the Chinese Revolution. Socialist Register, 12, 115-59.

Lewis, J. W. (1963). Leadership in Communist China. Ithaca: Cornell University Press.

Lin, C. (2006). The Transformation of Chinese Socialism. Durham: Duke University Press.

Liu, X. (2007). Minzhujizhongzhi [Democratic Centralism]. Beijing: Jiefangjunchubanshe.

Mao, Z. (1940). On New Democracy. In S. Schram (Ed.), Mao's Road to Power: Revolutionary Writings, 1912-1949, New Democracy, 1939-1941 (pp. 330-369, Vol. 7). Armonk, NY: M. E. Sharpe, 2005.

Mao, Z. (1945). On Coalition Government. In Selected Works of Mao Tse-tung (pp. 278-285, Vol. 3). Peking: Foreign Languages Press, 1967.

Mao, Z. (1957). On the Correct Handling of Contradictions among the People. In Selected Readings from the Works of Mao Tsetung (pp. 432-479). Peking: Foreign Languages Press, 1971.

Mao, Z. (1962). Talk at an Enlarged Central Work Conference. In S. Schram (Ed.), Chairman Mao Talks to the People: Talks and Letter, 1956-1971 (pp. 160-70). New York, NY: Pantheon, 1975.

Mao, Z. (1969). On the Mass Line. In S. Schram (Ed.), The Political Thought of Mao Tse-tung (pp. 315-17, Rev. and Enlarged ed.). New York, NY: Praeger.

Marx, K., \& Lenin, V. I. (1988). The Civil War in France: The Paris Commune (2nd ed.). New York, NY: International.

McCormick, B. L. (1990). Political Reform in Post-Mao China: Democracy and Bureaucracy in a Leninist State. Berkeley, CA: University of California Press.

Meisner, M. (2007). Mao Zedong: A Political and Intellectual Portrait. Cambridge: Polity.

Schram, S. (1969). The Political Thought of Mao Tse-tung (rev. ed.). New York, NY: Praeger.

Schram, S. (1989). The Thought of Mao Tse-tung. Cambridge: Cambridge University Press. https://doi.org/10.1017/CBO9780511521454

Selden, M. (1971). The Yenan Way in Revolutionary China. Cambridge: Harvard University Press.

Selden, M. (1995). Yan'an Communism Reconsidered. Modern China, 21, 8-44. https://doi.org/10.1177/009770049502100102

Shanghai Shi Dang'an Guan (SDDG). [Shanghai Municipal Archives].

Starr, J. B. (1979). Continuing the Revolution: The Political Thought of Mao. Princeton, NJ: Princeton University Press.

Steiner, H. A. (1966). Constitutionalism in Communist China. In G. P. Jan (Ed.), Government of Communist China (pp. 191-213). San Francisco, CA: Chandler.

Teiwes, F. C. (1990). Politics at Mao's Court: Gao Gang and Party Factionalism in the Early 1950s. Armonk, NY: M.E. Sharpe. 
Thornton, P. (2011). Retrofitting the Steel Frame: From Mobilizing the Masses to Surveying the Public. In S. Heilmann, \& E. J. Perry (Eds.), Mao's Invisible Hand: The Political Foundations of Adaptive Governance in China (pp. 237-268). Cambridge: Harvard University Press. https://doi.org/10.2307/j.ctt1sq5tc6.14

Trotsky, L. (2010). The Permanent Revolution and Results and Prospects. Seattle, WA: Red Letter Press.

Tsou, T. (1986). The Cultural Revolution and Post-Mao Reforms: A Historical Perspective. Chicago, IL: University of Chicago Press.

Vogel, E. (1967). From Revolutionary to Semi-Bureaucrat: The "Regularisation" of Cadres. China Quarterly, 29, 36-60. https://doi.org/10.1017/S0305741000047901

Vogel, E. (1969). Canton under Communism: Programs and Politics in a Provincial Capital, 1949-1968. Cambridge: Harvard University Press.

Walder, A. G. (1986). Communist Neo-Traditionalism: Work and Authority in Chinese Industry. Berkeley, CA: University of California Press.

Walker, R. L. (1955). China under Communism: The First Five Years. New Haven, CT: Yale University Press.

Wang, G. (1994). Lun minzhu he minzhujizhongzhi [On Democracy and Democratic Centralism]. Beijing: Zhongguoshehuikexuechubanshe.

Weatherley, R. (2006). Politics in China since 1949: Legitimizing Authoritarian Rule. London: Routledge.

Whyte, M. K. (1974). Small Groups and Political Rituals in China. Berkeley, CA: University of California Press.

Wong, Y. (2005). From Deng Xiaoping to Jiang Zemin: Two Decades of Political Reform in the People's Republic of China. Lanham, MD: University Press of America.

$\mathrm{Wu}$, Z. (1985-1986). Wushiniandai ganbulilunxuexi rechaoshiliang [The Upsurge in Strength of Theoretical Study among Cadres in the 1950s]. Wuhan Wenshiziliao, 49-50, 85-92.

Zhonggong Shanghai shiweidangyanjiushi (2011). Shanghai zhiyuanquanguo, 1949-1976 [Shanghai Supports the Entire Nation, 1949-1976]. Shanghai: Shanghai shudianchubanshe. 